http://dx.doi.org/10.4314/jae.v19i2.6

\title{
Assessment of Growth Enhancement Support Scheme among Rice Farmers in Anambra State, Nigeria
}

\author{
Nwalieji H.U. \\ Department of Agricultural Economics and Extension, \\ Chukwuemeka Odumegwu Ojukwu University, \\ Igbariam campus, Anambra State, Nigeria \\ Email nwalieji73@yahoo.com \\ Phone: 07033994751

\section{Uzuegbunam, C.O.} \\ Department of Agricultural Economics and Extension, \\ Chukwuemeka Odumegwu Ojukwu University, \\ Igbariam campus, Anambra State, Nigeria \\ Okeke M. N. \\ Department of Agricultural Economics and Extension, \\ Chukwuemeka Odumegwu Ojukwu University, \\ Igbariam campus, Anambra State, Nigeria
}

\begin{abstract}
The study assessed growth enhancement support (GES) scheme in Anambra State, Nigeria. The population of the study included all rice farmers that participated in the scheme in Anambra State. Multistage sampling was used, and a combination of purposive and simple random sampling techniques was used in selecting a total sample size of 100 respondents. Primary and secondary sources of data were used. Data collected were through the use of an interview schedule and the scheme's publications. Performance index, percentage and mean were used to analyze data. The result of the findings showed that the scheme had very low performance indices in redemption of inputs $14.7 \%$ and $32.4 \%$ in 2012 and 2013, respectively). The Scheme made great changes in food productivity ( $M=$ 2.70) and farmers' access to farm inputs $(M=2.55)$. Farmers had high level of satisfaction on the scheme's implementation processes in the areas of registration process and quantity of improved seed redeemed. Major challenges identified were poverty $(M=2.32)$, illiteracy $(M=2.45)$, poor awareness $(M=2.55)$, and poor mobile phone possession and usage $(M=$ 2.76). It was recommended that more awareness and adequate training be given to farmers for them to participate actively and for other farmers to join the scheme. Also there is need for the scheme to be passed into law to become policy for continuity and sustainability.
\end{abstract}

Keywords: Assessment of GES scheme, Anambra State 


\section{Introduction}

Nigeria government since independence in 1960 had established and launched several policies, programmes and projects in order to be self-food sufficient, food reliant and food secure. However, this was not achieved or in some cases minimal impacts were said to have been made (Babatunde and Oyatoye, 2005; Ojoko, 2014). According to Azubuike (2012) the country food insecurity status keeps increasing and the recent estimates put the number of hungry people in Nigeria at over 53 million, just less than 30 per cent of the country's total population estimated at 160 million. However, International Fund for Agricultural Development (IFAD) (2009) noted that the government recognizes the importance of empowering people to design and manage their own development activities. The current strategy for the protection of poor rural people includes efforts to strengthen: access to credit and land; participation in decision-making; access to agricultural extension services; access to improved seeds and planting materials, farm inputs and tools; traditional thrift, savings and insurance schemes.

Growth Enhancement Support (GES) Scheme was initiated by the Federal and State Governments under the Agricultural Transformation Agenda (ATA) for the provision of subsidized inputs to farmers in Nigeria (FRN, 2013). The GES, a special agricultural scheme of the Federal and State Governments, is aimed at delivering subsidized farm inputs to farmers and facilitating a shift from subsistence to commercial farming. It was designed as a component of the ATA of the Federal Government in 2012. The ATA is the current government's response to realizing food security and increasing household income for farmers at the micro level. With GES, the government seeks to withdraw from direct fertilizer purchase and distribution, and introduce an alternative system of distribution built on the voucher system. Under the scheme, registered farmers receive e-wallet vouchers with which they can redeem fertilizer and seeds from agro-input dealers (Fertilizer Suppliers Association of Nigeria (FESPAN), 2012). The GES is a three-year scheme and the first cycle was implemented in 2012 (http://www.tribune.com.ng).

Adesina (2012) noted that GES is a strategy by the Federal and State Governments under the ATA to provide subsidized inputs to farmers and ensure that the financial burden are shared among the two levels of Government and farmers. The Scheme according to him has put paid to the unwholesome activities of middle men who, over the years, had been diverting the products to neighbouring countries for their selfish end leaving only $11 \%$ of the products for use by the Nigerian farmers.

The Growth Enhancement Support (GES) Scheme represents a policy and pragmatic shift within the existing Fertilizer Market Stabilization Programme and it puts the resource constrained farmer at its centre through the provision of series of incentives to encourage the critical actors in the fertilizer value chain to work together to improve productivity, household food security and 
income of the farmers (Federal Ministry of Agriculture and Rural Development (FMARD), 2013). The goals of GESS are to:

- target 5 million farmers in each year for 4 years that will receive GESS in their mobile phone directly totalling 20 million at the end of 4 years;

- provide support directly to farmers to enable them procure agricultural inputs at affordable prices, at the right time and place;

- increase productivity of farmers across the length and breadth of the country through increased use of fertilizer i.e. $50 \mathrm{~kg} / \mathrm{ha}$ from $13 \mathrm{~kg} / \mathrm{h}$; and

- change the role of Government from direct procurement and distribution of fertilizer to a facilitator of procurement, regulator of fertilizer quality and catalyst of active private sector participation in the fertilizer value chain.

Adesina (2013) stated that GES is a strategy by the Federal and State Governments under the Agricultural Transformation Agenda (ATA) to provide subsidized inputs to farmers and ensure that the financial burden are shared among the two levels of Government and farmers. The GES Scheme was designed to enhance agricultural productivity through timely, efficient and effective delivery of yield-increasing farm input (FRN, 2013). The Scheme seeks to provide subsidized fertilizers and seeds directly to farmers through the electronic wallet system, which allows farmers to receive subsidized electronic vouchers on their mobile phones (National Association of Nigeria Traders (NANTS), 2013). The targeting of the farmers is based on the farmer registration exercise being conducted throughout the country (http://www.tribune.com.ng).

A recent stock-taking by the Federal Ministry of Agriculture and Rural Development shows that in 2012, 1.5 million smallholder farmers got their subsidized seeds and fertilizers using their mobile phones. It was also stated that 10 million farmers have been registered and now have identity cards which allow the use of biometric information to target them more effectively. Also, over 3.4 million farmers is said to have received their subsidized inputs in 2013, with the expectation that close to 5 million farmers will be reached by the end of the dry season (FMARD, 2013). According to Ojoko (2014), the expectation that GES scheme will bring out the best from both the small and large scale farmers all over the country, with full commitment of all the three tiers of government to agriculture. He further stated that the scheme will be more functional, efficient, generate employment, enhance farmer's income and reduce poverty and at the end make food security a dream come true.

Anambra State, Nigeria started participating in the scheme in 2012 in which both maize and rice farmers benefitted in the scheme. The questions are: to what extent had the scheme achieved its laudable objective in provision of farmers with inputs such as fertilizers and improved seeds at subsidized rate especially in Anambra State, Nigeria? What are the farmers' perceptions of changes brought about by the scheme on food production as well as access to farm inputs? What are the farmers' level of satisfaction and participation in the 
scheme? What are the challenges to effective implementation of the scheme? Answers to the foregoing questions are what the study provided. However, the research specifically covered only the rice farmers for clarity purposes.

\section{Objective of the study}

The major objective of the study was to assess growth enhancement support (GES) scheme in Anambra State, Nigeria. Specifically, the study was designed to:

1. determine extent of achievement of the scheme in providing farmers with inputs such as fertilizers and improved seeds;

2. assess farmers' perception of changes brought about by the scheme on food production as well as access to farm inputs;

3. determine farmers' level of satisfaction on the scheme's implementation processes; and

4. identify challenges to effective implementation of the scheme.

\section{Methodology}

The study was carried out in Anambra State, Nigeria. Anambra is made up of 21 Local Government Areas (LGAs) and four Agricultural Zones (AZs) Aguata, Anambra, Awka and Onitsha. It is located in the South-East region of Nigeria between longitude $6^{\circ} 36^{\prime} \mathrm{E}$ and $7^{\circ} 21^{\prime} \mathrm{E}$ and latitude $5^{\circ} 38^{\prime} \mathrm{N}$ and $6^{\circ}$ $47^{\prime} \mathrm{N}$. Anambra State occupies an area of $4,416 \mathrm{sq}$. $\mathrm{km}$ and has a population of $4,177,828$ out of which $2,117,984$ are male and 2,059,844 female (NPC, 2006). The number of farm families is 338,721 with an average size of 6 persons per farm family or household (ASADEP, 2011). The climate is typically equatorial with two main seasons, the dry and the rainy seasons. The vegetation consists of rainforest. Other parts consist of woody savannah and grasslands. Crops, livestock and fisheries are main stock in the farming system of the state. Offfarm activities like processing and marketing are also vital components. Major crops grown in the state among others include rice, cassava, yam, maize, okra, cocoyam, melon, cowpea and pigeon pea. The State has a population of about 25,000 registered rice farmers (ASADEP, 2011).

The population of the study included all rice farmers that participated in the scheme in Anambra State, Nigeria. Multi-stage, purposive and simple random sampling techniques were used in selecting a total sample size of 100 respondents.

The first stage involved the purposive selection of two agricultural zones (Awka and Anambra) that are notable for rice production activities in the state. In the second stage, three extension blocks were purposively selected from Anambra zone while two extension blocks were selected from Awka Agricultural zone due to high rice production activities. This gave a total of five extension blocks 
involved in the study and they included Dunukofia and Awka North in Awka zone; Anambra East, Ayamelum and Oyi in Anambra zone.

The third stage involved the selection of two extension circles from each of the selected extension blocks. This gave a total of ten extension circles. From each of these circles, ten GES Scheme beneficiaries were selected using simple random sampling technique. This gave a total of 100 farmers that serve as sample size for the study.

Primary and secondary sources were used for data collection. Primary data were obtained through the use of interview schedule administered to farmers. Secondary data were obtained from the scheme's publications and reports.

To determine extent of achievement of the scheme in providing farmers with inputs such as fertilizers and improved seeds, a performance index was used. The information on target and achievement of the scheme in 2012 and 2013 with respect to provision of inputs such as fertilizers and improved seeds were retrieved from the project's publications and reports. These included the number of: farmers registered and served, number of fertilizers and improved seeds redeemed.

The performance index (P.I.) was computed as:

$\frac{\text { Actual }}{\text { Expected }} \times \frac{100}{1}$ or $\frac{\text { Achievement }}{\text { Target }} \times \frac{100}{1}$

When P.I. $\geq 0.50$ or $\geq 50.0 \%$ shows that the performance is on the average or high.

To assess farmers' perception of changes brought about by the scheme on food production as well as access to farm inputs, the farmers were asked to indicate on a 3-point Likert-type scale their perception of extent of changes due to the scheme's intervention. Their response categories were: to a great extent $(\mathrm{TGE})=3$; to little extent $(\mathrm{TLE})=2$; to no extent $(\mathrm{TNE})=1$. These values were added to obtain a value of 6 which was divided by 3 to get a mean score of 2.0 in each case. Any mean score $\geq 2.0$ was regarded as great change, while any mean score $<2.0$ was regarded as little or no change.

To determine farmers' level of satisfaction on the scheme's implementation processes, farmers were asked to indicate on a 3-point Likert-type scale their level of satisfaction on the scheme's implementation processes. Their response categories were: very satisfactory $=3$; satisfactory $=2$; unsatisfactory $=1$. These values were added to obtain a value of 6 which was divided by 3 to get a mean score of 2.0 in each case. Any mean score $\geq 2.0$ was regarded as satisfactory implementation process, while any mean score $<2.0$ was regarded as unsatisfactory implementation process.

To identify the major challenges in implementing the scheme, the beneficiaries were asked to indicate on a 3-point Likert-type scale, how serious each of the 
various shortlisted challenges militates against effective implementation of the scheme. Their response categories were: very serious (VS) $=3$; serious $(S)=$ 2 ; and not serious (NS) $=1$. These values were added to obtain a value of 6 which was divided by 3 to get a mean score of 2.0. The respondents' mean were obtained on each of the items. Any mean score $\geq 2.0$ was regarded as a serious problem/major challenge; while any mean score $<2.0$ was regarded as not serious problem/minor challenge.

Performance index, percentage and mean statistics were used to analyze data.

\section{Results and Discussion}

\section{Extent of GES scheme achievement in providing farmers with inputs in Anambra State}

Table 1 shows that the actual total number of registered farmers in 2012 was 106,598 while 5,022 farmers out of the registered farmers were given service delivery redemption, leaving a very low performance index of $4.7 \%$. This implies that out of the total number of farmers participated in the scheme during the year 2012, only very few redeemed their input. In 2013, the number of farmers that participated in the scheme by registrations rose to 199,901 giving a percentage increase of $87.5 \%$ from $2012-2013$. Also, 64,842 farmers out of 199,901 registered farmers received service delivery redemption thereby giving about $32 \%$ performance index in service delivery, while percentage increase between the years 2012 and 2013 rose very high to $1,438.0 \%$. The finding shows that there is yearly increase in farmers' participation and service delivery redemption in the scheme. This is in line with FMARD (2014) which reported that no fewer than 10 million farmers have been captured in the database of the GES scheme currently being implemented by the FMARD in conjunction with private sector firms. According to the information, an increasing number of farmers have been captured in recent months following the success of the scheme in 2012.

Entries in Table1 further reveal that farmers redeemed 631bags and 68,668 bags of NPK in 2012 and 2013, respectively giving very high percentage increase of $10,782.4 \%$. Also farmers redeemed 61,017 bags of Urea fertilizer, 12,000 bags (units of $12.5 \mathrm{~kg}$ ) of rice, and $59,36410 \mathrm{~kg}$ bags of improved maize seeds in 2013 and no data were recorded in 2012. Furthermore, in 2013 under system usage and phone penetration, data in the same table reveal that about $70 \%$ of the farmers had phone penetration while $45 \%$ had valid phone. This implies that the majority of the farmers still have problem with phones as only source of information in accessing or redeeming their inputs. 
Table 1: Performance indices of GES Scheme in Anambra State between 2012 and 2013

\begin{tabular}{|c|c|c|c|c|c|c|c|}
\hline \multirow[b]{2}{*}{ Performance index } & \multicolumn{3}{|c|}{ Year 2012} & \multicolumn{3}{|c|}{ Year 2013} & \multirow{2}{*}{$\begin{array}{l}\% \text { increase } \\
\text { from } 2012- \\
2013\end{array}$} \\
\hline & $\mathrm{T}$ & A & Index \% & $\mathrm{T}$ & A & Index \% & \\
\hline $\begin{array}{l}\text { Number of registered farmers- } \\
\text { participation }\end{array}$ & - & 106,598 & - & - & 199,901 & - & 87.5 \\
\hline $\begin{array}{l}\text { Number of farmers served- service } \\
\text { delivery redemption }\end{array}$ & 106,598 & 5,022 & 4.7 & 199,901 & 64,842 & 32.4 & $1,438.0$ \\
\hline Number of NPK (units of $50 \mathrm{~kg}$ ) & - & 631 & - & - & 68,668 & - & $10,782.4$ \\
\hline Number of Urea units of $50 \mathrm{~kg}$ & NA & NA & - & - & 61,017 & - & - \\
\hline Number of rice units of $12.5 \mathrm{~kg}$ & NA & NA & - & - & 12,000 & - & - \\
\hline Number of maize units of $10 \mathrm{~kg}$ & NA & NA & - & - & 59,364 & - & - \\
\hline Phone penetration & NA & NA & - & - & $70 \%$ & - & - \\
\hline$\%$ of farmers with valid phone & NA & NA & - & - & $45 \%$ & - & - \\
\hline
\end{tabular}

Source: 2012 /2013 GES Farmer Redemption Dash Board (FMARD, 2013).

$T=$ targeted; $A=$ achieved; $P . I . \geq 50 \%=$ high performance index; $N A=$ Not applicable

\section{Rice farmers' perception of changes brought about by the scheme}

Data in Table 2 show that the respondents agreed that the scheme brought great changes in the following activities $(M \geq 2.00)$ : increase in yield $(M=2.70)$, access to fertilizers at subsidized rate $(M=2.55)$, and access to improved seeds $(\mathrm{M}=2.55)$. There was no change in hectrages of land cultivated with low weighted mean of 1.85 as a result of the scheme's intervention. This implies that the scheme made great changes in food productivity and farmers' access to farm inputs such as fertilizer and improved seeds.

Table 2: Mean distribution of respondents according to their perception of changes brought about by the scheme on food production as well as access to farm inputs

\begin{tabular}{lll}
\hline Activities & Mean (M) & SD \\
\hline Increase in yield & $2.70^{\star}$ & 0.462 \\
Access to fertilizers at subsidized rate & $2.55^{\star}$ & 0.700 \\
Access to improved seeds & $2.55^{\star}$ & 0.650 \\
Increase in hectrage of land cultivated & 1.85 & 0.713 \\
\hline
\end{tabular}

Source: Field survey, 2014; * $=M \geq 2.00$ = great change; $S D=$ standard deviation

\section{Farmers' level of satisfaction on the scheme's implementation processes}

Table 3 shows that the rice farmers had high level of satisfaction on the scheme's implementation processes/activities only in the areas of registration process $(\mathrm{M}=2.15)$ and quantity of improved maize/rice seed allocated/redeemed $(M=2.85)$. However, the farmers had unsatisfactory implementation process/activities in the areas of GES Scheme awareness $(M=$ $1.90)$, timely access to information on the scheme $(M=1.65)$, redemption 
process $(M=1.46)$, quantity of fertilizer allocated/redeemed $(M=1.54)$, and use of phone as source of information in input redemption $(M=1.65)$. This implies that farmers are not satisfied in most of the scheme's implementation processes/activities.

This is an indication, for instance the farmers were not given adequate awareness for massive participation in the scheme; and there was untimely access to information on the scheme in many cases. The redemption process was rigorous and disappointing in many cases and in different locations. Quantity of fertilizer ( 2 bags of $50 \mathrm{~kg}-1 \mathrm{NPK} \& 1$ Urea) allocated/redeemed was not enough for the majority of farmers that cultivate 1 hectare of land and above. Also use of phone as source of information in input redemption was quite disappointing all round. These are in line with FESPAN (2012) which reported that farmers in most parts of the country especially Calabar were unable to receive text messages with e-wallet system due to poor network from telecommunications service providers, making it difficult to get their packages.

\section{Table 3: Mean distribution of respondents according to their level of satisfaction on the scheme's implementation processes}

\begin{tabular}{lll}
\hline Activities & \multicolumn{2}{c}{ Level of satisfaction } \\
& Mean & SD \\
\hline GES Scheme awareness & 1.90 & 0.605 \\
Registration process & $2.15^{\star}$ & 0.425 \\
Timely access to information on the scheme & 1.65 & 0.768 \\
Redemption process & 1.46 & 0.804 \\
Quantity of fertilizer allocated/redeemed & 1.54 & 0.799 \\
Quantity of improved rice seed allocated/redeemed & $2.85^{\star}$ & 0.413 \\
Use of phone as source of information in input redemption & 1.65 & 0.768 \\
\hline
\end{tabular}

${ }^{*} M \geq 2.00$ = satisfactory implementation process. Source: Field survey, 2014;

\section{Major challenges in implementing the scheme}

Table 4 shows the mean distribution of identified challenges to effective implementation of the scheme in the study area. The data reveal that illiteracy $(M=2.45)$; poor awareness $(M=2.55)$; poor mobile phone possession and usage $(M=2.76)$; poverty $(M=2.32)$; corruption $(M=2.55)$; poor network (ewallet strategy) $(M=2.33)$; political $(M=2.05)$; difficulty in redeeming input $(M=$ $2.68)$; late supply of agro-input $(M=2.72)$; poor quality of fertilizer supplied $(M=$ 2.10); and inadequate number of fertilizers supplied at redemption centre $(M=$ 2.35) were the major challenges. However, inadequate manpower $(M=1.88)$ and transportation $(M=1.65)$ were regarded as minor challenges. This implies that despite some success stories of the scheme, it still faces many serious challenges which should be taken into considerations for it to stand a test of time.

The illiteracy nature of the farmers may be the contributory factor that makes it impossible for them to access the inputs through the use of phone. Poverty as result of lack of capital to redeem the allocated inputs is still posing some 
challenges. Corruption in form of input diversion by staff and input dealers thereby not reaching the targeted small-scale farmers is a major challenge facing the scheme. Poor network many at times made it difficult to receive text messages with e-wallet system thereby posing challenges to farmers in getting their packages. Political challenge in which farmers' registration, input allocation and distributions are being politicized thereby depriving real farmers from benefitting from the scheme. Bottleneck in the scheme brings about difficulty in redeeming input. The finding is in line with Adesina (2012) who noted that aim of GES scheme initiative was to reform the fertilizer distribution system which was riddled with corruption. He said only about 11 per cent of farmers ever got the subsidized fertilizer in the past. The rest of it was diverted by officials and shared to well-connected politicians or sold to marketers, leading to a loss of about N776 billion government funds between 1980 and 2010.

\section{Table 4: Mean distribution of respondents according to major challenges in implementing the scheme}

\begin{tabular}{lll}
\hline Challenge & Mean (M) & SD \\
\hline Illiteracy & $2.45^{\star}$ & 0.645 \\
Poor awareness & $2.55^{\star}$ & 0.622 \\
Poor mobile phone possession and usage & $2.76^{*}$ & 0.436 \\
Poverty & $2.32^{*}$ & 0.705 \\
Corruption & $2.55^{\star}$ & 0.634 \\
Poor network (e-wallet strategy) & $2.33^{*}$ & 0.737 \\
Inadequate manpower & 1.88 & 0.812 \\
Political & $2.05^{\star}$ & 0.785 \\
Transportation & 1.65 & 0.892 \\
Difficulty in redeeming input & $2.68^{\star}$ & 0.455 \\
Late supply of agro-input & $2.72^{*}$ & 0.413 \\
Poor quality of fertilizer supplied & $2.10^{*}$ & 0.774 \\
Inadequate number of fertilizers supplied at redemption & $2.35^{\star}$ & 0.713 \\
centre & &
\end{tabular}

Source: Field survey, $2014 ;{ }^{*}=$ major challenge $(M \geq 2.00)$

\section{Conclusion and Recommendations}

The scheme had very low performance indices in redemption of inputs, although there are yearly increase in farmers' participation and service delivery redemption in the scheme. The scheme brought great changes in increase in yield, access to fertilizers at subsidized rate and access to improved seeds. Farmers had high level of satisfaction on the scheme's implementation processes/activities only in the areas of registration process and quantity of improved rice seed allocated/redeemed. The identified major challenges to effective implementation of the scheme in the study area included illiteracy, poor awareness, poor mobile phone possession and usage, poverty, 
corruption, poor network (e-wallet strategy), political, difficulty in redeeming input, late supply of agro-input, poor quality of fertilizer supplied and inadequate number of fertilizers supplied at redemption centre.

The following recommendations are made:

1. More awareness and adequate training be given to farmers by the extension arm of the scheme for them to participate actively and for other farmers to join the scheme.

2. The management of the scheme should ensure early provision or supply of fertilizers and improved seeds to farmers for optimum utilization.

3. Since network poses great challenges under e-wallet system in which farmers do not receive text messages on their phones, the authority should use alternative means such as voucher cards to ensure that farmers get their packages. Here, farmers whose names are in the register can produce any form of identification such as driving license or voters' registration card to claim their inputs.

4. There is need for the National Assembly to pass GES into law/policy for continuity and sustainability.

\section{References}

Adesina, A. (2012 December 28). Growth enhancement support scheme. Save Agricultural sector. Punch newspaper. Retrieved from http://www.punch.ng.com/business/industryGESS

Adesina, A. (2013 January 15). Nigeria, no going back on cell phones. Vanguard newspaper. Retrieved from http://www.vanguardngr.com

Anambra State ADP (ASADEP) (2011). End of year 2011 report.

Azubuike, G. (2008). Nigerian food insecurity as a time bomb. Retrieved on 23/04/14 from http://allafrica.com.stories/201203110293.html.A.E.Obayelu@A.O.Obay elu.2012.

Babatunde, R.O. (2005). Food scarcity and marketing problems in Nigeria: The Case of maize marketing in Kwara State. International Conference on Research for Development in Agricultural Forestry, Food and Natural Resources Management.

Federal Ministry of Agriculture and Rural Development (FMARD) (2014 June 30). $10 \mathrm{~m}$ farmers captured in agric e-wallet scheme. New Telegraph. Retrieved on 15 march 2015 from newtelegraphonline.com 
Federal Ministry of Agriculture and Rural Development (FMARD), Nigeria (2013). GES live data dashboard. Retrieved on 02/12/2014 from http://www.fmard.gov..ng/ges-live-data-dashboard

Federal Republic of Nigeria (FRN) (2013). FG intensifies efforts at guaranteeing farmers' access to inputs, flags-off 2nd phase of GES in South West.

Fertilizer Suppliers Association of Nigeria (FESPAN) (2012). Working together to improve fertilizer supply in Nigeria. Newsletter, vol. 2 (8). Retrieved on 25/02/2015 from

http://fepsannigeria.com/files/Newsletter\%2520Vol\%25202\%2520No\%2 5208.pdf http://www.tribune.com.ng. GES review: Mixed feelings as stakeholders brainstorm on way forward. March 05, 13.

International Fund for Agricultural Development (IFAD) (2009). Enabling poor rural people to overcome poverty in Nigeria. Retrieved on $9^{\text {th }}$ June, 2012 from http://www.ifad.org/operatons/projects/regions

National Association of Nigeria Traders (NANTS) (2013). Opportunities for improving the growth enhancement scheme (GES). Agricultural News. Retrieved on 02/12/2014 from http://nants.org/

National Population Commission (NPC) (2006). 2006 census results. Retrieved on 24th October 2012 from http://www. npc.gov

Ojoko, E. (2014). Growth enhancement support scheme (GESS) and the challenges of food security in Nigeria: A review. Asian Research Publishing Network (ARPN) Journal of Agricultural and Biological Science, Vol. 9, No. 7, July ISSN 1990-6145 